\title{
Phenotypic and molecular characterization of Candida species in urine samples from renal failure patients
}

\author{
Mohammed S. Alhussaini ${ }^{1, *}$, Noha F. El-Tahtawi ${ }^{2}$, AhmadM. Moharram³ \\ ${ }^{1}$ Department of Clinical Laboratory Sciences, College of Applied Medical Sciences, Shaqra University, Saudi Arabia \\ ${ }^{2}$ Department of Clinical Laboratory Sciences, College of Applied Medical Sciences, Al-Dawadmi, Shaqra University, Saudi Arabia \\ ${ }^{3}$ Department of Botany and Microbiology, Faculty of Science,Assuit University,Egypt
}

\section{Email address:}

malhussaini@su.edu.sa (M. S. Alhussaini)

\section{To cite this article:}

Mohammed S. Alhussaini, Noha F. El-Tahtawi, AhmadM. Moharram. Phenotypic and Molecular Characterization of Candida Species in Urine Samples from Renal Failure Patients. Science Journal of Clinical Medicine. Vol. 2, No. 1, 2013, pp. 14-25.

doi: $10.11648 /$ j.sjcm.20130201.13

\begin{abstract}
The prevalence of Candida infections of the urinary tract (candiduria)has increased significantly over the past few years due to various predisposing factors especially in hospitalized patients. The predisposing factors frequently associated with candiduria are urinary tract instrumentation, prior antibiotic use, prolonged hospital stay, extremes of age, diabetes mellitus, female sex and use of immunosuppressive therapy. The purpose of this study was to apply different diagnostic techniques for characterization of Candida species in urine samples from renal failure patients using urinary catheters. Results showed that $20 \%$ of renal failure patients were suffering from candiduria. Females were more affected than males (64\% versus $36 \%$ of culture positive cases). Diabetes mellitus and catheterization were the obvious risk factors. Different Candida isolates showed variations in their phenotypic (macroscopic and microscopic) characteristics when cultured on CHROMagar Candida, corn meal agar and bovine serum. Candida albicans was the most common species being isolated from 54\% of positive cases. C.krusei (Teleomorph: Pichia kudriavzevii), C. glabrata and C.tropicalis were respectively identified in $24 \%, 16 \%$ and $6 \%$ of samples. Positive germ tube test (in serum) and production of chlamydospores (on corn meal agar) were only confined to C. albicans. Sequencing of rRNA gene (18S covering ITS1 and ITS2) confirmed the identification of the four Candida species. In vitro antifungal sensitivity test (disc diffusion method) revealed that all Candida strains were inhibited by Amphotericin-B and Nystatin. Other compounds as Clotrimazole, Itraconazole, Ketoconazole, Tioconazole, Fluconazole and Sertaconazole were effective against 50\% - 67\% of Candida strains. All isolates of C. glabrata were resistant to Clotrimazole and Sertaconazole.It is highly recommended to follow standard hygienic precautions to avoid cross contamination by Candida during hemodialysis. Complications following candiduria can be avoided by early diagnosis and proper treatment with effective antifungal agents.
\end{abstract}

Keywords: Candiduria, Renal Failure Patients, Chromagar Candida, RNA Gene Sequencing

\section{Introduction}

Candiduria or presence of Candida species in the urine is rarely encountered in otherwise healthy people with structurally normal urinary tract (Bukhary,2008,Kauffman, 2005 and Schonebeck and Ansehn, 1972). It is, however, of common occurrence in hospitalized patients. Candida spp. account for almost $10-15 \%$ of nosocomial urinary tract infections (UTIs) (Kauffman,2005, Lundstrom and Sobel, 2001 and Kauffman et al., 2000).In the United States, Shay and Miller (2004) estimated that the incidenceof candiduria was 25,000 cases per year. Moreover, approximately onethird of hospitalized patients with urine cultures yielding
Candida were in the Intensive care unit (ICU) where bladder catheter use was high. However, as early as 1986 Platt and colleagues reported that $26.5 \%$ of all UTIs with bladder catheter usage were due to Candida species. This observation was later substantiated by others who found that $90 \%$ of Candida UTIs in a large tertiary care centre in the United States were related to bladder catheters (Berrouane et al., 1999). On a national scale, surveillance studies have indicated that $25 \%$ of all UTIs in ICUs are caused by Candida species (Banerjee et al., 1999 and Jarvis et al.,1999) and the length of stay in such units influences the incidence significantly.

Candiduria is a frequently documented condition in ICU, but it remains a common dilemma, faced by clinicians, 
whether determining if a patient is suffering from a fungal infection or if the fungal presence is only due to normal colonization. In hospitalized patients, the urinary tract (UT) is one of the most propitious anatomical sites for the development of infections, once it is normally colonized by such microorganisms (Schaberg et al., 1991; Guler et al., 2006). However, the lack of a proper and safer protocol to characterize candiduria as a UT infection isusually a serious problem (Kauffman, 2005). On the other hand, candiduria has been considered an early marker of disseminated fungal infection in critically ill patients.

The genus Candida includes several species implicatedin human pathology such as C. albicans, C. tropicalis, C. parapsilosis, C. glabrata, C. krusei, C. lusitaniae, C. kefyr, C. guilliermondii and C. dubliniensis(Sulivan etal. , 1995).Candida albicans is by far the most common cause of mucosal yeast infection, being the sole species recovered from up to $70 \%$ of HIV infected individuals and up to $90 \%$ of cases of Candida vaginitis (Coleman et al., 1993; Sobel, 2007). Other Candida species can be recovered alone or coisolated with C. albicans from sites of mucosal infection (Coleman et al.,1995).

C. albicans has been the yeast most commonly isolated from urine, accounting for $50 \%-70 \%$ of isolates in various studies. C. glabrata and C. tropicalis are the next most common species found in cultures of urine. Candida parapsilosis, a common cause of candidemia in both adults and neonates, is uncommonly isolated from urine ofadults (Kauffman et al.,2000 ; Ayeni et al.,1999 and Stofer et al.,1994).C. parapsilosis is found more often in urine from neonates and is usually associated with systemic infection in this population (Wainer et al.,1997).In Brazil Vidigal et al (2011) reported a candiduria case in a 64-year-old male patient from intensive care unit (ICU) who developed candiduria due to C.tropicalis, which complicated to fatal candidemia despite antifungal treatment.

Researches in many laboratories is carried out to develop new drugs or drug delivery systems, but the development of approaches that allows quick and accurate identification of disease-causing yeasts is also necessary, especially because the incidence of human disease caused by the less common Candida species has increased. Thus, the identification of Candida species is very important in the diagnostic laboratory, because such identification shows prognostic and therapeutical significance,allowing the early and correct antifungal therapy (Godoy et al., 2001, Milan and Zaror, 2004).

The purpose of this study was to identify different Candida spp. isolated from renal failure patients by phenotypic and genotypic methods and to evaluate their sensitivity or resistance to currently used antifungal therapeutic agents.

\section{Material and Methods}

\subsection{Collection of Urine Samples}

Urine samples were collected from 250 patients visiting the University Hospitals in Cairo, Assiut and Sohag Governorates, Egypt during July and August 2012. All patients were complaining of renal failure (150males and 100 females) and frequently use urine catheters for more than 10 days.

\subsection{Phenotypic Identification of CandidaIsolates}

\subsubsection{A- Culturing on Sabouraud's Dextrose Agar (SDA)}

All samples were cultured onto Sabouraud's Dextrose Agar (SDA) (HiMedia, Mumbai, India) plates supplemented with $0.05 \%(\mathrm{~W} / \mathrm{V})$ chloramphenicol(Bhavan et al., 2010).Cultures were incubated at $37^{\circ} \mathrm{C}$ for $24-48$ hours after which the growing fungi were purified and kept in slants for further phenotypic and molecular studies.

\subsubsection{B-Culturing on CHROMagar Candida}

Chromogenic media contain chromogenic substrates which react with enzymes secreted by the target microorganisms to yield colonies of varying colours (Pfaller et al., 1996).CHROMagar Candida Differential agar (CHROMagar Company, Paris, France) is a selective and differential medium, which facilitates rapid isolation and presumptive identification of some yeasts from mixed cultures.The medium contained $(\mathrm{g} / \mathrm{L})$ : agar 15 ; peptone 10.2 ; chromogenic mix 22; chloramphenicol $0.5 ; \mathrm{pH}: 6.1$. According to the manufacturer 47.7 grams of the powdered medium were slowly dispersed in 1 liter of sterile distilled water and brought to a boil by repeated heating until complete fusion of agar grains. The medium was cooled in a water bath to $45-50^{\circ} \mathrm{C}$, with gentle stirring, then poured into sterile Petri dishes and allowed to solidify. Separate colonies from all Candida isolates on SDA were subcultured onto CHROMagar Candida and incubated at $37^{\circ} \mathrm{C}$ for $48 \mathrm{hr}$. Presumptive identification was done based on colony colour of the growing Candida strains.

\subsubsection{C-Germ-Tube Test}

Small inoculum of suspected Candida cultures were inoculated into $1 \mathrm{ml}$ of human serum (Sigma-Aldrich, Germany) in a small tube and incubated at $37^{\circ} \mathrm{C}$ for 2 hours. After incubation, a loop-full of culture was placed on a glass slide, overlaid with a cover-slip and examined microscopically for the presence or absence of germ-tubes. Formation of germ tubes was seen as long tube like projections extending from the yeast cells with no constriction or septa at the point of attachment to the yeast cells. The germ tube is indicative of C. albicans and C. dubliniensis (Bhavan et al., 2010).

\subsubsection{D-Culturing on Corn Meal Tween 80 Agar (CMA)}

As recommended by Koehler et al. (1999) and Ellis et al. (2007), chlamydospore formation by certain Candida species (C. albicans and C. dubleniensis) is a encouraged by culturing on CMA. This test is negative with other Candida species.

All yeast isolates were subcultured on SDA and and in glycerol water $(15 \% \mathrm{~V} / \mathrm{V})$ and kept under low temperature 
for further molecular and in vitro antifungal sensitivity test. Isolates were also given a code number assigned to the Assiut University Mycological Centre (AUMC).

\subsubsection{Genotypic Identification of Yeast Isolates}

Fungi were individually grown on Sabouraud's Dextrose agar and incubated at $37^{\circ} \mathrm{C}$ for 2 days. A small amount of fungal growth was scraped and suspended in $100 \mu 1$ of distilled water and boiled at $100^{\circ} \mathrm{C}$ for 15 minutes and stored at $-70^{\circ}$ C. Cultures were sent to SolGent Company (Daejeon, South Korea) for rRNA gene sequencing. Fungal DNA was extracted and isolated using SolGent purification bead. Prior to sequencing, the ribosomal rRNA gene (also referred to as rDNA) was amplified using the polymerase chain reaction (PCR) technique in which two universal fungal primers ITS1 (forward) and ITS4 (reverse) were incorporated in the reaction mixture. Primers used for gene amplification have the following composition: ITS1 (5' TCC GTA GGT GAA CCT GCG G - 3'), and ITS4 (5'TCC TCC GCT TAT TGA TAT GC -3'). The rRNA gene is composed of the following regions: small subunit (SSU) which is the $18 \mathrm{~S}$ region, the ITS1, the $5.8 \mathrm{~S}$, the ITS2 and the large subunit (LSU)which is the $28 \mathrm{~S}$ region as shown in Fig 1. The PCR reaction mixture was prepared using Solgent EF-Taq as follows: 10X EF-Taq buffer $2.5 \mu 1,10 \mathrm{mM}$ dNTP (T) $0.5 \mu \mathrm{l}$, primer (Forward-10 picomol) $1.0 \mu \mathrm{l}$, primer (Reverse -10 picomol) $1.0 \mu \mathrm{l}$, EF-Taq polymerase (2.5U) $0.25 \mu \mathrm{l}$, DNA template $1.0 \mu \mathrm{l}$, Distilled Water (to 25 $\mu \mathrm{l})$. Then the amplification was carried out in a thermal cycler under the following conditions: one round of denaturation at $95^{\circ} \mathrm{C}$ for $15 \mathrm{sec}$ followed by 30 cycles of denaturation at $95^{\circ} \mathrm{C}$ for $20 \mathrm{sec}$, annealing at $50^{\circ} \mathrm{C}$ for $40 \mathrm{sec}$ and extension at $72^{\circ} \mathrm{C}$ for $1 \mathrm{~min}$, with a final extension step at $72 \mathrm{C}$ for $5 \mathrm{~min}$.

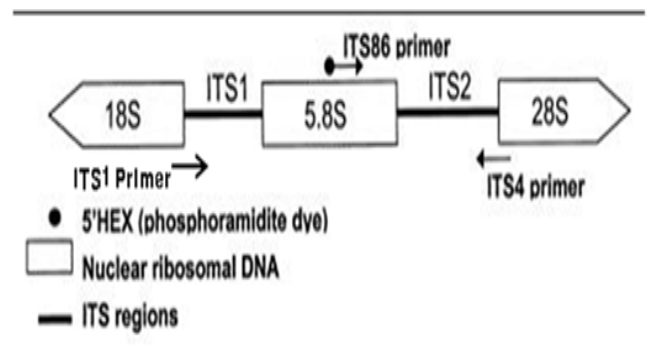

Fig.1. Schematic representation of the fungal ribosomal gene containing the primer target areas used in the amplification of the $18 S$ region (partial sequencing), ITS1, 5.8S, ITS2 (complete sequencing) and $28 S$ (partial sequencing).

The PCR products were then purified with the SolGent PCR Purification Kit-Ultra (SolGent, Daejeon, South Korea) prior to sequencing. The purified PCR products were reconfirmed (using size marker) by electrophoreses on $1 \%$ agarose gel. Then these bands were eluted and sequenced with the incorporation of dideoxynucleotides (dd NTPs) in the reaction mixture. Each sample was sequenced in the sense and antisense directions using ITS1 and ITS4 primers. Sequences were further analyzed using BLAST from the National Center of Biotechnology Information (NCBI) website. Phylogenetic analysis of sequences was done with the help of MegAlign (DNA Star) software version 5.05.

\subsubsection{Antifungal Susceptibility Test}

The disc diffusion test was performed according to the procedure described in the Clinical and Laboratory Standard Institute (CLSI, 2004). Cell suspensions of individual Candida strains were prepared in $2 \mathrm{ml}$ of sterile $0.85 \%$ saline solution. The turbidity was adjusted to yield 0.5 McFarland standard (approximately $5 \times 10^{3}$ cells $/ \mathrm{ml}$. Six kinds of antifungal agents obtained from HiMedia Company in India were tested. The interpretative breakpoints of these antifungal agents were done according to Ellis (2011a) as shown in table 1 .

Table 1. Interpretative breakpoints of antifungal agents.

\begin{tabular}{|c|c|c|c|c|}
\hline \multirow{2}{*}{$\begin{array}{l}\text { Antifungal agents } \\
\text { (Abbreviation) }\end{array}$} & \multirow{2}{*}{$\begin{array}{l}\text { Concentration } \\
\text { /disc }\end{array}$} & \multicolumn{3}{|c|}{ Zone of activity in mm } \\
\hline & & Sensitive & Intermediate & Resistant \\
\hline $\begin{array}{l}\text { Amphotericin-B } \\
\text { (AM-B) }\end{array}$ & $100 \mathrm{U}$ & $\geq 15$ & $10-14$ & $<10$ \\
\hline Nystatin (NYS) & $100 \mathrm{U}$ & $\geq 15$ & $10-14$ & $<10$ \\
\hline Clotrimazole (CLO) & 10ug & $\geq 20$ & $12-19$ & $\leq 11$ \\
\hline Fluconazole (FLU) & 10ug & $\geq 19$ & $15-18$ & $\leq 14$ \\
\hline Itraconazole (ITR) & 10ug & $\geq 23$ & $14-22$ & $\leq 13$ \\
\hline Ketoconazole (KET) & 10ug & $\geq 28$ & $21-27$ & $\leq 20$ \\
\hline Sertaconazole (SER) & 10ug & $\geq 23$ & $14-22$ & $\leq 13$ \\
\hline Tioconazole (TIO) & 10ug & $\geq 23$ & $14-22$ & $\leq 13$ \\
\hline
\end{tabular}

\section{Results and Discussion}

\subsection{Prevalence of Candiduria in Relation to Sex and Age of Patients}

Of the 250 renal failure patients studied, 150 were males and 100 were females. Candiduria was confirmed in only 50 patients ( $20 \%$ of total cases) by positive culturing on Sabouraud's agar medium. Among these cases, 32 (64\%) were females and the remaining $18(36 \%)$ were males (Tables2 \&3). The age of Candida infected persons was ranging from 27 to 80 years. These results are nearly similar to those reported by Ang et al .(1993) who found that the incidence of candiduria was $6.5-20 \%$ among hospitalized patients. Pfaller et al. (1991) reported that the frequency was $22.1 \%$ and is strongly associated with the presence of a urinary catheter. Slightly higher frequencies $(25 \%$ and 28.7\%) have been reported by Badawi et al.(2004) and Pakshir et al. (2004) respectively.

The higher prevalence of candiduria in females than in males confirms the work of Passos et al.(2005) who found that the percent of candiduria in females was $61.6 \%$ compared to $38.4 \%$ in males. More recently, Rashwan et 
al.(2010) observed candiduria in $34.4 \%$ females versus $14.9 \%$ in males. A plausible explanation of this phenomenon is the presence of Candida in the genital tract of women complaining of vaginal candidiasis. This also confirms the work of Febre et al. (1999) who found five of eight patients with positive vaginal secretions and later showed the presence of the same yeast species in their urine.

Table 2. Epidemiology of candiduria, characteristics of yeasts cultured onSDA, CMA and CA Candida media and identification after phenotyping and (*rDNA sequencing).

\begin{tabular}{|c|c|c|c|c|c|c|c|}
\hline Case No. & $\begin{array}{l}\text { Age } \\
\text { by years }\end{array}$ & Sex & $\begin{array}{l}\text { Diabetes } \\
\text { mellitus }\end{array}$ & $\begin{array}{l}\text { Growth } \\
\text { On SDA agar }\end{array}$ & Color on CA & $\begin{array}{l}\text { Chlamydo-spores } \\
\text { on CMA }\end{array}$ & $\begin{array}{l}\text { Identification } \\
\text { based on rDNA sequencing }\end{array}$ \\
\hline 1 & 67 & Male & + & $\begin{array}{l}\text { Budding cells \& } \\
\text { Hyphae }\end{array}$ & Pink & - & $\begin{array}{l}\text { Candida krusei } \\
\text { (Teleomorph: Pichiakudriavzevii) }\end{array}$ \\
\hline 2 & 75 & Male & - & $\begin{array}{l}\text { Budding cells \& } \\
\text { Hyphae }\end{array}$ & Blue & - & C. tropicalis* \\
\hline 3 & 53 & Female & - & $\begin{array}{l}\text { Budding cells \& } \\
\text { Hyphae }\end{array}$ & Pink & - & $\begin{array}{l}\text { C. kruse }{ }^{*} \text { (Teleomorph: Pichia } \\
\text { kudriavzevii) }\end{array}$ \\
\hline 4 & 35 & Female & - & $\begin{array}{l}\text { Budding cells \& } \\
\text { Hyphae }\end{array}$ & Green & + & C. albicans* \\
\hline 5 & 49 & Male & + & $\begin{array}{l}\text { Budding cells \& } \\
\text { Hyphae }\end{array}$ & Pink & - & $\begin{array}{l}\text { C. krusei } \\
\text { (Tel: Pichiakudriavzevii) }\end{array}$ \\
\hline 6 & 54 & Female & - & $\begin{array}{l}\text { Budding cells \& } \\
\text { Hyphae }\end{array}$ & Green & + & C. albicans \\
\hline 7 & 44 & Male & - & Budding cells & Green & + & C. albicans \\
\hline 8 & 45 & Female & - & $\begin{array}{l}\text { Budding cells \& } \\
\text { Hyphae }\end{array}$ & Pink & - & $\begin{array}{l}\text { C. krusei } \\
\text { (Tel: Pichiakudriavzevii) }\end{array}$ \\
\hline 9 & 55 & Female & - & $\begin{array}{l}\text { Budding cells \& } \\
\text { Hyphae }\end{array}$ & Green & + & C. albicans \\
\hline 10 & 57 & Male & - & Budding cells & Pink & - & C. glabrata* \\
\hline 11 & 70 & Female & + & Budding cells & Green & + & C. albicans \\
\hline 12 & 68 & Female & - & $\begin{array}{l}\text { Budding cells \& } \\
\text { Hyphae }\end{array}$ & Pink & - & $\begin{array}{l}\text { C. krusei } \\
\text { (Tel: Pichiakudriavzevii) }\end{array}$ \\
\hline 13 & 70 & Female & - & $\begin{array}{l}\text { Budding cells \& } \\
\text { Hyphae }\end{array}$ & Green & + & C. albicans \\
\hline 14 & 65 & Female & - & Budding cells & Pink & - & C. glabrata* \\
\hline 15 & 45 & Male & - & $\begin{array}{l}\text { Budding cells \& } \\
\text { Hyphae }\end{array}$ & Pink & - & $\begin{array}{l}\text { C. krusei } \\
\text { (Tel: Pichiakudriavzevii) }\end{array}$ \\
\hline 16 & 75 & Male & - & $\begin{array}{l}\text { Budding cells \& } \\
\text { Hyphae }\end{array}$ & Green & + & C. albicans \\
\hline 17 & 60 & Female & + & Budding yeast & Pink & - & C. glabrata* \\
\hline 18 & 37 & Female & - & $\begin{array}{l}\text { Budding cells \& } \\
\text { Hyphae }\end{array}$ & Pink & - & $\begin{array}{l}\text { C. krusei } \\
\text { (Tel: Pichiakudriavzevii) }\end{array}$ \\
\hline 19 & 38 & Male & - & $\begin{array}{l}\text { Budding cells \& } \\
\text { Hyphae }\end{array}$ & Green & + & C. albicans \\
\hline
\end{tabular}



species in urine samples from renal failure patients

\begin{tabular}{|c|c|c|c|c|c|c|c|}
\hline Case No. & $\begin{array}{l}\text { Age } \\
\text { by years }\end{array}$ & Sex & $\begin{array}{l}\text { Diabetes } \\
\text { mellitus }\end{array}$ & $\begin{array}{l}\text { Growth } \\
\text { On SDA agar }\end{array}$ & Color on CA & $\begin{array}{l}\text { Chlamydo-spores } \\
\text { on CMA }\end{array}$ & $\begin{array}{l}\text { Identification } \\
\text { based on rDNA sequencing }\end{array}$ \\
\hline 20 & 72 & Female & - & $\begin{array}{l}\text { Budding cells \& } \\
\text { Hyphae }\end{array}$ & Green & + & C. albicans \\
\hline 21 & 44 & Female & + & Budding cells & Green & + & C. albicans \\
\hline 22 & 78 & Male & + & Budding cells & Pink & - & C. glabrata \\
\hline 23 & 68 & Female & - & $\begin{array}{l}\text { Budding cells \& } \\
\text { Hyphae }\end{array}$ & Blue & - & C. tropicalis \\
\hline 24 & 27 & Male & - & Budding cells & Green & + & C. albicans \\
\hline 25 & 80 & Female & - & Budding cells & Green & + & C. albicans \\
\hline 26 & 42 & Male & - & $\begin{array}{l}\text { Budding cells } \\
\& \text { Hyphae }\end{array}$ & Blue & - & C. tropicalis \\
\hline 27 & 30 & Female & - & $\begin{array}{l}\text { Budding cells } \\
\& \text { Hyphae }\end{array}$ & Green & + & C. albicans \\
\hline 28 & 47 & Female & - & Budding cells & Green & + & C. albicans \\
\hline 29 & 33 & Female & + & $\begin{array}{l}\text { Budding cells } \\
\& \text { Hyphae }\end{array}$ & Green & + & C. albicans \\
\hline 30 & 43 & Male & - & $\begin{array}{l}\text { Budding cells } \\
\& \text { Hyphae }\end{array}$ & Pink & - & $\begin{array}{l}\text { C. krusei } \\
\text { (Tel: Pichiakudriavzevii) }\end{array}$ \\
\hline 31 & 39 & Female & - & Budding cells & Pink & - & C. glabrata* \\
\hline 32 & 40 & Male & - & Budding cells & Green & + & C. albicans \\
\hline 33 & 37 & Male & - & $\begin{array}{l}\text { Budding cells \& } \\
\text { Hyphae }\end{array}$ & Green & + & C. albicans \\
\hline 34 & 36 & Female & - & $\begin{array}{l}\text { Budding cells } \\
\& \text { Hyphae }\end{array}$ & Green & + & C. albicans \\
\hline 35 & 51 & Male & + & Budding cells & Green & + & C. albicans \\
\hline 36 & 31 & Female & - & Budding cells & Green & + & C. albicans \\
\hline 37 & 28 & Male & - & $\begin{array}{l}\text { Budding cells } \\
\& \text { Hyphae }\end{array}$ & Pink & - & $\begin{array}{l}\text { C. krusei } \\
\text { (Tel: Pichiakudriavzevii) }\end{array}$ \\
\hline 38 & 53 & Female & - & $\begin{array}{l}\text { Budding cells } \\
\& \text { Hyphae }\end{array}$ & Green & + & C. albicans \\
\hline 39 & 35 & Female & - & Budding cells & Green & + & C. albicans \\
\hline 40 & 31 & Female & - & $\begin{array}{l}\text { Budding cells } \\
\& \text { Hyphae }\end{array}$ & Green & + & C. albicans \\
\hline 41 & 34 & Male & + & $\begin{array}{l}\text { Budding cells } \\
\& \text { Hyphae }\end{array}$ & Blue & - & C. tropicalis \\
\hline
\end{tabular}




\begin{tabular}{|c|c|c|c|c|c|c|c|}
\hline Case No. & $\begin{array}{l}\text { Age } \\
\text { by years }\end{array}$ & Sex & $\begin{array}{l}\text { Diabetes } \\
\text { mellitus }\end{array}$ & $\begin{array}{l}\text { Growth } \\
\text { On SDA agar }\end{array}$ & Color on CA & $\begin{array}{l}\text { Chlamydo-spores } \\
\text { on CMA }\end{array}$ & $\begin{array}{l}\text { Identification } \\
\text { based on rDNA sequencing }\end{array}$ \\
\hline 42 & 50 & Female & - & Budding cells & Pink & - & C. glabrata* \\
\hline 43 & 54 & Female & - & Budding cells & Pink & - & C. glabrata \\
\hline 44 & 43 & Female & - & $\begin{array}{l}\text { Budding cells } \\
\& \text { Hyphae }\end{array}$ & Green & + & C. albicans \\
\hline 45 & 34 & Female & - & $\begin{array}{l}\text { Budding cells } \\
\& \text { Hyphae }\end{array}$ & Green & + & C. albicans \\
\hline 46 & 37 & Male & + & $\begin{array}{l}\text { Budding cells } \\
\& \text { Hyphae }\end{array}$ & Pink & - & $\begin{array}{l}\text { C. krusei } \\
\text { (Tel: Pichiakudriavzevii) }\end{array}$ \\
\hline 47 & 55 & Female & - & Budding cells & Green & + & C. albicans \\
\hline 48 & 75 & Female & - & Budding cells & Pink & - & C. glabrata* \\
\hline 59 & 77 & Female & - & Budding cells & Green & + & C. albicans \\
\hline 50 & 32 & Female & - & $\begin{array}{l}\text { Budding cells } \\
\text { \& Hyphae }\end{array}$ & Pink & - & $\begin{array}{l}\text { C. krusei } \\
\text { (Tel: Pichiakudriavzevii) }\end{array}$ \\
\hline
\end{tabular}

\subsection{Risk Factors for Candiduria}

All patients investigated in this study were urinary catheterized (Table 3).According to Klotz and Smith (1990) yeasts are able to adhere to the catheter, allowing colonization in this device. Passos et al.(2005) showed that in92.6\% cases of candiduria the patients had a urinary catheter. Similar results have also been given by Kobayashi et al. (2004) who verified that $84.4 \%$ of the patients with candiduria had a catheter. Álvarez-Lerma et al. (2003) mentioned that although infection by yeasts in patients with indwelling urinary catheter has not been well defined till now, use of invasive procedures has been reported as an important factor for development of Candida infection.

Table 3.Summary of cases of candiduria and germ tube test of Candida strains.

\begin{tabular}{ll}
\hline Criteria & Number (\%) \\
\hline Gender & Total $=50$ \\
Males & $18(36 \%)$ \\
Females & $32(64 \%)$ \\
Cathetarization & $50(100 \%)$ \\
Diabetes mellitus & $10(20 \%)$ \\
Males & $6(12 \%)$ \\
Females & $4(8 \%)$ \\
Germ tube test & Total $=50$ \\
Positive & $27(54 \%)$ Candida albicans strains \\
Negative & $23(46 \%)$ Non-Candida albicans strains \\
\hline
\end{tabular}

Results of the present study (Tables $2 \& 3$ ) showed also that $10(20 \%)$ of Candida infected patients were diabetic with males outnumbering females ( 6 versus 4 cases). Previous reports showed higher prevalence of candiduria $(36.7 \%)$ in diabetes mellitus patients (Behiry et al.,2010). During their study of risk factors for nosocomial candiduria, Guler et al. (2006) showed that candiduria was increased by 12 -fold after urinary catheterization, 6-fold each after use of broad spectrum antibiotics and urinary tract abnormalities, 4-fold following abdominal surgery, 2-fold in the presence of diabetis mellitus and one-fold in association with corticosteroid administration.

\subsection{Phenotypic Characteristics of CandidaIsolates}

Preliminary identification of the different Candida isolates was successfully done using conventional phenotypic methods which included growth on (SDA), germ tube test, formation of pseudohyphae, chlamydospore production and colony colour on chromogenic media (Table 2).

a.Growth on Sabauroud's dextrose agar (SDA):

All Candida isolates showed good growth on (SDA). Colonies were white to cream in colour, smooth, glabrous and yeast- like in appearance. Microscopic morphology showed spherical to subspherical budding yeast cells with several isolates producing pseudohyphae. Although simple and inexpensive, these criteria are not enough for identification for Candida species.

b. Growth on corn meal tween 80 agar (CMA):

All cultures of Candida grew well on this medium but only $27 / 50(54 \%)$ were able to produce chlamydospores suggestive of C. albicans (see table 2).

c. Germ tube formation by Candida isolates:

In the present work germ-tube production was observed in $27 / 50$ (54\%) of Candida strains, which were identified 
as C. albicans whereas the remaining strains $46 \%$ failed to produce germ-tubes, being identified as non-Candida albicans (Table 2 and Fig. 2). This ratio is markedly lower than that reported by Kangogo et al.(2011), who found 112/130 (86\%) of Candida spp. produced germ-tubes and were identified as Candida albicans and 18/130 (13.9\%) were identified as non-Candida albicans. The germ-tube production test has the advantage to be simple and efficient in the economical and fast identification of C. albicans (Fisher and Cook,1998 and Lacaz et al.,2002). Some authors evaluated sensitivity and specificity of the germ-tube test, finding results between 93 and $98.8 \%$, and between 73.3 and $100 \%$, respectively (Cambell et al.,1998; Conceicao et al.,2005 and Gatica et al.,2002).

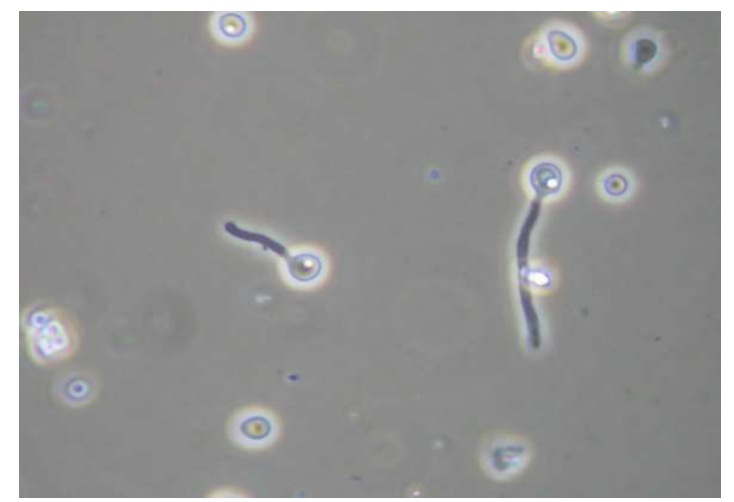

Figure 2.Germ tube of C. albicans (magnification x 400) by phase contrast microscope.

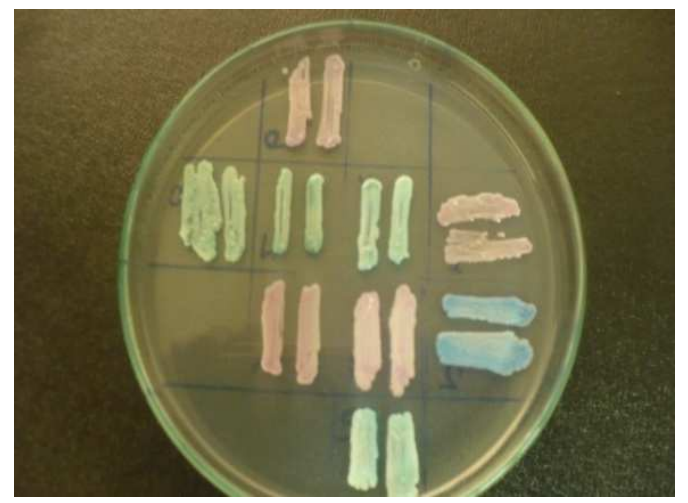

Figure 3. Colony colors on CHROMagar Candida medium. Light green: C. albicans, Dark blue : C. tropicalis, pink: C. glabrata and C. krusei.

d. Growth on Chromagar Candida (CA) medium:

Results of the present study (Table 3) revealed that (27/50) $54 \%$ of Candida isolates yielded several shades of green colonies on CA suggestive of $C$. albicans. Only (20/50) $40 \%$ of isolates developed a pink color suggestive of C. krusei or C. glabrata. Discrimination of these two species was possible on the basis that $C$. krusei can form both budding cells and pseudohyphae whereas $C$. glabrata is not able to produce peudohyphae (Ellis et al., 2007). Accordingly $C$. krusei and C. glabrata were represented by $24 \%$ and $16 \%$ of total Candida is in renal failure patients. The present data showed also that $6 \%$ of Candida isolates developed a distinctive dark blue color on CA typical of $C$. tropicalis. Chromogenic media have the advantage of rapid identification of Candida species, technically simple preparation (by boiling), rapid and cost effective compared to technically demanding time consuming and expensive conventional method (Vijaya et al., 2011).There are several reports confirming the high prevalence of $C$. albicans in urine samples (Weinberger et al., 2003). Among all fungi isolated from the urine, $40-65 \%$ was found to be C. albicans (Vincent et al., 1998). In their study performed with 751 patients with candiduria, Kauffman et al.(2000) found that $C$. albicans was present in $51.8 \%$ and C. glabrata in $15.6 \%$ of the patients. Weinberger et al. (2003) isolated $C$. albicans in $56.4 \%, C$. tropicalis in $19 \%, C$. glabrata in $15.7 \%, C$. parapsilosis is in $6.1 \%$ and $C$. krusei in $1.8 \%$ of the cases. Although the prevalence of $C$. albicans is higher, the proportion of non- Candida fungi involved in urinary pathogenesis increases over the course of time (Vincent et al., 1998). Orovcova et al. (1996) observed C. albicans in $72 \%$ of the cases and non- Candida albicans pathogens in $28 \%$, in their series of 50 patients. More recently, Kangogo et al. (2011) recorded that out of the 150 isolates130/150 $(86.7 \%)$ yielded several shades of green colonies and identified as C. albicans. Only 4/150 (2.7\%) of isolates produced pink colonies on CA typical of C.krusei and also $2.7 \%$ of isolates developed a dark blue colour typical of C. tropicalis. In Egypt, Girgis et al. (2009) found that the average counts of Candida spp. isolated from urine samples were 21.14, 14.14, 15.14 and $8.35 \mathrm{CFU} / \mathrm{ml}$ for C. albicans, $C$. glabrata, C. tropicalis and $C$. parapsilosis, respectively during the sampling period. The minimum counts were 18, 11, 11 and $5 \mathrm{CFU} / \mathrm{ml}$ for Candida albicans, Candida glabrata, Candida tropicalis and Candida parapsilosis, respectively. While the maximum counts were 24, 17, 19 and $12 \mathrm{CFU} / \mathrm{ml}$ for these species respectively. The highest counts of isolated Candida spp. were C. albicans in urine samples, while the lowest counts were $C$. parapsilosis during the sampling months. In New York, USA, Jain et al. (2007) obtained 67 Candida isolates from urine samples from 55 patients. The species distribution was C. albicans (54\%), C. glabrata (36\%), and C. tropicalis (10\%).

\subsection{Molecular Characterization of Candida Isolates}

Ten representative isolates of C. albicans, C. tropicalis (one isolate for each), C. krusei (5) and C. glabrata (3) were chosen for rRNA gene sequencing. After sequence alignment and establishment of the phylogenetic tree, identification of these isolates was confirmed especially when compared with the type strains accessed from the Gene bank (Fig.2). The phylogenetic tree showed four well defined clades clearly distinguishing the four different species of Candida. The first is the C. tropicalis clade which comprises strain assigned AUMC 9236 recovered in the present work from urine compared to other closely related strains from different sources in the world. The second clade comprised C. albicans(AUMC 9239) compared to the type strain of the same species (NRRL Y-12983T) and others. Clade 3 included Pichia kudriavzevii which is the teleo- 
morphic (ascosporic) state of C. krusei.

Yeasts of the genus Pichia are widely distributed; they can be found in natural habitats, such as soil, freshwater, tree exudates, insects, plants and fruits, and also as contaminants in a variety of foods and beverages. Some Pichia species contribute desired effects in the early stages of wine fermentation, several types of brines, and different types of cheeses; while others have been described as human pathogens (Bakir et al., 2003; Otag et al., 2005).

The fourth clade in Fig. 2 is the C. glabrata which comprised the type strain of this species (ATCC 2001T= NRRL Y-65T ).

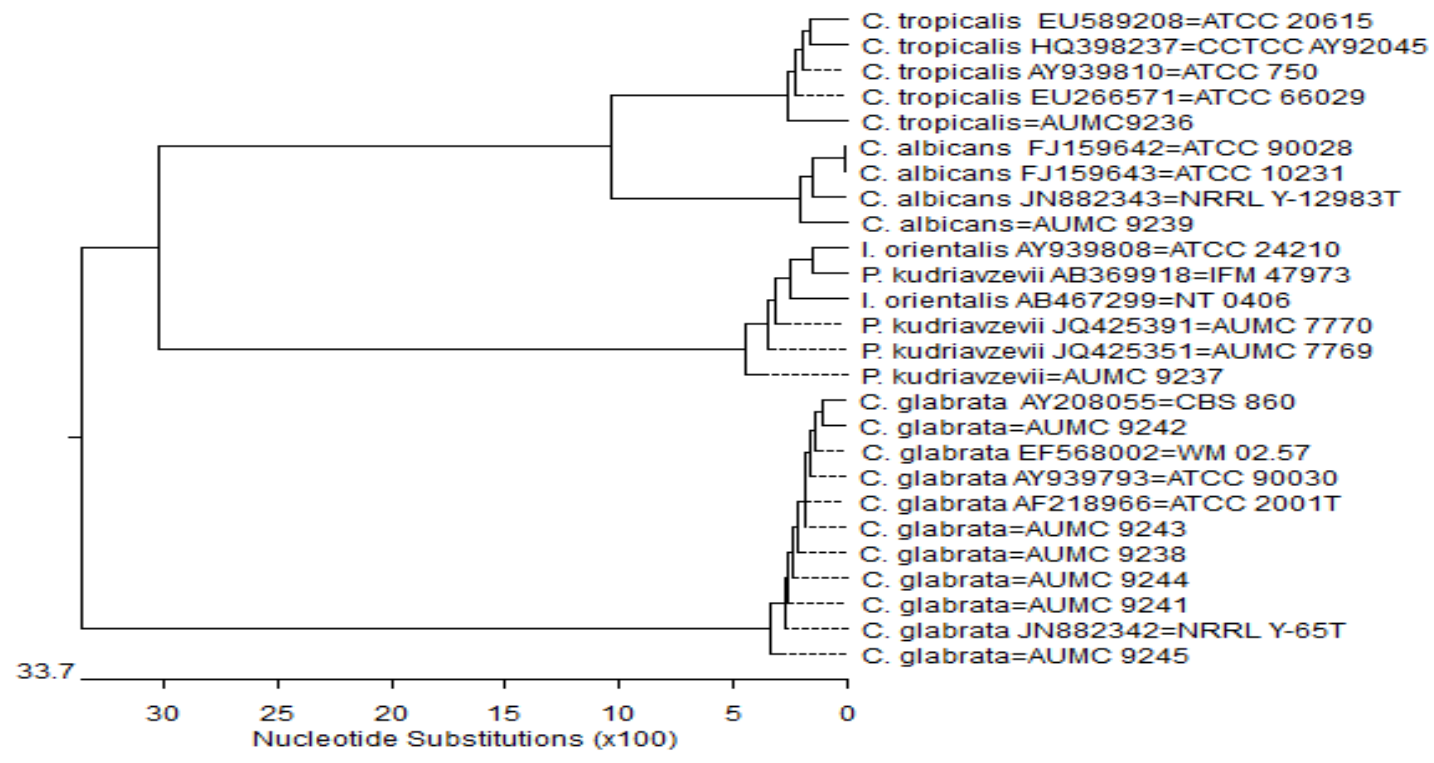

Fig 4. Phylogenetic tree for fungal species isolated from urine sample of renal failure patientsin Egypt (given AUMC Numbers), C=Candida, I = Issatchenkia, and $P=$ Pichia. Yeast species from Gene bank are given accession Numbers (e.g. EU589208, etc.)The scale indicates the number of nucleotide substitutions per site. Reference type strains (T) of corresponding fungi are involved in the tree (given CBS, ATCC, CCTCC, NRRL, IFM, NT, and WM numbers.

It is worthy to mention that the genotypic identification based on rRNA gene sequencing showed close agreement with phenotypic identification for all Candida species studied in this investigation. However, molecular techniques have the advantages of relatively processing time and high sensitivity and specificity. The amplification feature of the PCR assay make it ideal for detecting low yeast levels from minimal volume of clinical samples. DNA based diagnosis tests have also the potential to decrease the time taken for the laboratory identification of pathogens that are growing slowly or difficult to culture (Khlif et al.,2007). Moreover, rapid identification of the fungal pathogens such as Candi$d a$ species may help to reduce the hospital stay and high overall costs associated with management of Candida infections and is also of great value in epidemiological studies.

\subsection{Sensitivity of Candida Isolates to Antifungal Thera- peutic Agents}

The data presented in table 3 and Fig. 5 revealed that Nystatin was the most active drug against the majority of Candia strains tested (36/37 strains). Also high proportion of Candida strains was sensitive to Clotrimazole, Amphoterici-B and Tioconazole (28, 26, and 20 strains respectively). On the other hand the highest number of resistant Candida strains was observed with Sertaconazole (29/37), followed in a descending order by Itraconazole (21), Fluconazole (19), Tioconazole (15) and Clotrimazole (9). Resistance to Nystatin and Amphotericin-B was only exhibited by 1 and 2 strains respectively. All isolates of C. glabrata (9 tested isolates) were completely resistant to Fluconazole and Sertaconazole. Among the 7 isolates of C. krusei only two were susceptible to Fluconazole. These findings are nearly similar to those reported by Nawrat et al. (2000) who found Amphotericin-B effective against $100 \%$ of Candida isolates. The same authors noticed also that $72.1 \%$ of Candida strains were sensitive to Ketoconazole, $61.4 \%$ to Fluconazole and $47.1 \%$ to Itraconazole. The study of Kronvall and Karlsson (2001) showed that Most Candida strains were susceptible to Fluconazole with the exception of C. glabrata and C. Krusei. Working with 270 isolates of Candida, Ellis (2011b) showed that all isolates of C. albicans were susceptible to Fluconazole and Clotrimazole. Resitance to Fluconazole was manifested by $20 \%$ of $C$. glabrata isolates. As suggested by Bukhary (2008), Fluconazole is the drug of choice if the organism isolated is not C. glabrata or $C$. krusei. Oral fluconazole has a more delayed but more lasting effect on candiduria than Amphotericin-B bladder irrigation. Patients receiving Amphotericin-B bladder irrigation had higher rates of eradication two days after the beginning of therapy than those receiving oral Fluconazole but the cure rates were similar one month after the beginning of therapy. According to Sobel et al. (2000), treatment 
with Fluconazole , 200mg/day, for $7-14$ days or with intravenous Amphotericin-B deoxycholate at doses 0.3 $1.0 \mathrm{mg} / \mathrm{kg} /$ day for $1-7$ days has been successful based on moderate evidence from a randomised clinical trial.

In conclusion, more work is still needed to cover more hospitals and a broader spectrum of patients complaining of candiduria. Discovery of new antifungal agents effective against Candida strains resistant to the currently used antifungal is a must.

Table 4. Sensitivity of Candida species to antifungalagents (Zone of activity in mm expressed as Sensitive (S), Intermediate (I) and Resistant (R).

\begin{tabular}{|c|c|c|c|c|c|c|c|c|c|}
\hline \multicolumn{2}{|c|}{$\begin{array}{l}\text { Antifungal agents } \\
\text { Strain No. and Name }\end{array}$} & \multirow{2}{*}{$\begin{array}{l}\text { AM-B } \\
\text { (100U) }\end{array}$} & \multirow{2}{*}{$\begin{array}{l}\text { CLO (10 } \boldsymbol{\mu g}) \\
22 \mathrm{~S}\end{array}$} & \multirow{2}{*}{$\begin{array}{l}\text { FLU } \\
(\mathbf{1 0 \mu g})\end{array}$} & \multirow{2}{*}{$\begin{array}{l}\begin{array}{l}\text { ITR } \\
(10 \mu g)\end{array} \\
15 \mathrm{I}\end{array}$} & \multirow{2}{*}{$\begin{array}{l}\begin{array}{l}\text { KET } \\
(10 \mu g)\end{array} \\
00 \mathrm{R}\end{array}$} & \multirow{2}{*}{$\begin{array}{l}\text { NYS (100U) } \\
23 \mathrm{~S}\end{array}$} & \multirow{2}{*}{$\begin{array}{l}\text { SER } \\
(10 \mu g)\end{array}$} & \multirow{2}{*}{$\begin{array}{l}\text { TIO } \\
(\mathbf{1 0 \mu g})\end{array}$} \\
\hline 9206 & C. krusei & & & & & & & & \\
\hline 9207 & C. albicans & $10 \mathrm{I}$ & $22 \mathrm{~S}$ & $27 \mathrm{~S}$ & $13 \mathrm{R}$ & $20 \mathrm{I}$ & $25 \mathrm{~S}$ & $12 \mathrm{I}$ & $27 \mathrm{~S}$ \\
\hline 9208 & C. albicans & $22 \mathrm{~S}$ & $24 \mathrm{~S}$ & $34 \mathrm{~S}$ & $17 \mathrm{I}$ & $23 \mathrm{I}$ & $28 \mathrm{~S}$ & $00 \mathrm{R}$ & $00 \mathrm{R}$ \\
\hline 9209 & C. krusei & $15 \mathrm{~S}$ & $25 \mathrm{~S}$ & $15 \mathrm{I}$ & $12 \mathrm{R}$ & $00 \mathrm{R}$ & $20 \mathrm{~S}$ & $00 \mathrm{R}$ & $20 \mathrm{~S}$ \\
\hline 9210 & C. albicans & $10 \mathrm{I}$ & $7 \mathrm{R}$ & $00 \mathrm{R}$ & $00 \mathrm{R}$ & $00 \mathrm{R}$ & $24 \mathrm{~S}$ & $00 \mathrm{R}$ & $10 \mathrm{R}$ \\
\hline 9211 & C. glabrata & $18 \mathrm{~S}$ & $00 \mathrm{R}$ & $00 \mathrm{R}$ & $16 \mathrm{I}$ & $25 \mathrm{I}$ & $28 \mathrm{~S}$ & $00 \mathrm{R}$ & $00 \mathrm{R}$ \\
\hline 9213 & C. krusei & $13 \mathrm{I}$ & $00 \mathrm{R}$ & $00 \mathrm{R}$ & $00 \mathrm{R}$ & $00 \mathrm{R}$ & $25 \mathrm{~S}$ & $10 \mathrm{R}$ & $00 \mathrm{R}$ \\
\hline 9214 & C. albicans & $11 \mathrm{I}$ & $27 \mathrm{~S}$ & $27 \mathrm{~S}$ & $15 \mathrm{I}$ & $22 \mathrm{I}$ & $25 \mathrm{~S}$ & $00 \mathrm{R}$ & $23 \mathrm{~S}$ \\
\hline 9215 & C. glabrata & $16 \mathrm{~S}$ & $00 \mathrm{~S}$ & $00 \mathrm{R}$ & $00 \mathrm{R}$ & $00 \mathrm{R}$ & $35 \mathrm{~S}$ & $11 \mathrm{R}$ & $00 \mathrm{R}$ \\
\hline 9217 & C. albicans & $25 \mathrm{~S}$ & $00 \mathrm{~S}$ & $28 \mathrm{~S}$ & $00 \mathrm{R}$ & $22 \mathrm{I}$ & $28 \mathrm{~S}$ & $11 \mathrm{R}$ & $00 \mathrm{R}$ \\
\hline 9218 & C. glabrata & $17 \mathrm{~S}$ & $00 \mathrm{~S}$ & $00 \mathrm{R}$ & $00 \mathrm{R}$ & $00 \mathrm{R}$ & $32 \mathrm{~S}$ & $00 \mathrm{R}$ & $00 \mathrm{R}$ \\
\hline 9219 & C. krusei & $24 \mathrm{~S}$ & $27 \mathrm{~S}$ & $27 \mathrm{~S}$ & $20 \mathrm{I}$ & $32 \mathrm{~S}$ & $30 \mathrm{~S}$ & $15 \mathrm{I}$ & $27 \mathrm{~S}$ \\
\hline 9220 & C. albicans & $24 \mathrm{~S}$ & $24 \mathrm{~S}$ & $23 \mathrm{~S}$ & $10 \mathrm{R}$ & $17 \mathrm{R}$ & $38 \mathrm{~S}$ & $00 \mathrm{R}$ & $18 \mathrm{I}$ \\
\hline 9221 & C. albicans & $22 \mathrm{~S}$ & $26 \mathrm{~S}$ & $25 \mathrm{~S}$ & $16 \mathrm{I}$ & $26 \mathrm{I}$ & $32 \mathrm{~S}$ & $00 \mathrm{R}$ & $31 \mathrm{~S}$ \\
\hline 9222 & C. albicans & $8 \mathrm{R}$ & $00 \mathrm{R}$ & $00 \mathrm{R}$ & $00 \mathrm{R}$ & $00 \mathrm{R}$ & $19 \mathrm{~S}$ & $00 \mathrm{R}$ & $00 \mathrm{R}$ \\
\hline 9223 & C. glabrata & $13 \mathrm{I}$ & $21 \mathrm{~S}$ & $00 \mathrm{R}$ & $11 \mathrm{R}$ & $22 \mathrm{I}$ & $25 \mathrm{~S}$ & $00 \mathrm{R}$ & $10 \mathrm{R}$ \\
\hline 9224 & C. tropicalis & $25 \mathrm{~S}$ & $27 \mathrm{~S}$ & $00 \mathrm{R}$ & $15 \mathrm{I}$ & $26 \mathrm{I}$ & $32 \mathrm{~S}$ & $11 \mathrm{R}$ & $27 \mathrm{~S}$ \\
\hline 9225 & C. albicans & $22 \mathrm{~S}$ & $24 \mathrm{~S}$ & $00 \mathrm{R}$ & $17 \mathrm{I}$ & $00 \mathrm{R}$ & $26 \mathrm{~S}$ & $12 \mathrm{I}$ & $30 \mathrm{~S}$ \\
\hline 9226 & C. albicans & $22 \mathrm{~S}$ & $26 \mathrm{~S}$ & $26 \mathrm{~S}$ & $15 \mathrm{I}$ & $00 \mathrm{R}$ & $37 \mathrm{~S}$ & $00 \mathrm{R}$ & $20 \mathrm{~S}$ \\
\hline 9227 & C. tropicalis & $21 \mathrm{~S}$ & $26 \mathrm{~S}$ & $00 \mathrm{R}$ & $16 \mathrm{I}$ & $00 \mathrm{R}$ & $37 \mathrm{~S}$ & $7 \mathrm{R}$ & $25 \mathrm{~S}$ \\
\hline 9229 & C. albicans & $23 \mathrm{~S}$ & $30 \mathrm{~S}$ & $27 \mathrm{~S}$ & $13 \mathrm{R}$ & $24 \mathrm{I}$ & $34 \mathrm{~S}$ & $9 \mathrm{R}$ & $28 \mathrm{~S}$ \\
\hline 9230 & C. albicans & $18 \mathrm{~S}$ & $23 \mathrm{~S}$ & $26 \mathrm{~S}$ & $12 \mathrm{R}$ & $20 \mathrm{R}$ & $23 \mathrm{~S}$ & $10 \mathrm{R}$ & $26 \mathrm{~S}$ \\
\hline 9231 & C. krusei & $23 \mathrm{~S}$ & $26 \mathrm{~S}$ & $00 \mathrm{R}$ & $16 \mathrm{I}$ & $00 \mathrm{R}$ & $26 \mathrm{~S}$ & $11 \mathrm{R}$ & $27 \mathrm{~S}$ \\
\hline 9232 & C. glabrata & $22 \mathrm{~S}$ & $25 \mathrm{~S}$ & $00 \mathrm{R}$ & $16 \mathrm{I}$ & $25 \mathrm{I}$ & $35 \mathrm{~S}$ & $10 \mathrm{R}$ & $30 \mathrm{~S}$ \\
\hline 9233 & C. albicans & $23 \mathrm{~S}$ & $28 \mathrm{~S}$ & $00 \mathrm{R}$ & $15 \mathrm{I}$ & $00 \mathrm{R}$ & $35 \mathrm{~S}$ & $7 \mathrm{R}$ & $25 \mathrm{~S}$ \\
\hline 9234 & C. albicans & $13 \mathrm{I}$ & $23 \mathrm{~S}$ & $32 \mathrm{~S}$ & $11 \mathrm{R}$ & $24 \mathrm{I}$ & $25 \mathrm{~S}$ & $00 \mathrm{R}$ & $23 \mathrm{~S}$ \\
\hline 9235 & C. albicans & $20 \mathrm{~S}$ & $29 \mathrm{~S}$ & $00 \mathrm{R}$ & $15 \mathrm{I}$ & $25 \mathrm{I}$ & $25 \mathrm{~S}$ & $17 \mathrm{I}$ & $28 \mathrm{~S}$ \\
\hline 9236 & C. tropicalis & $13 \mathrm{I}$ & $19 \mathrm{~S}$ & $20 \mathrm{~S}$ & $13 \mathrm{R}$ & $22 \mathrm{I}$ & $25 \mathrm{~S}$ & $00 \mathrm{R}$ & $21 \mathrm{~S}$ \\
\hline 9237 & C. krusei & $10 \mathrm{I}$ & $25 \mathrm{~S}$ & $12 \mathrm{R}$ & $11 \mathrm{R}$ & $13 \mathrm{R}$ & $25 \mathrm{~S}$ & $16 \mathrm{I}$ & $13 \mathrm{I}$ \\
\hline 9239 & C. albicans & $15 \mathrm{~S}$ & $25 \mathrm{~S}$ & $22 \mathrm{~S}$ & $12 \mathrm{R}$ & $17 \mathrm{R}$ & $25 \mathrm{~S}$ & $21 \mathrm{I}$ & $23 \mathrm{~S}$ \\
\hline 9241 & C. glabrata & $10 \mathrm{I}$ & $00 \mathrm{R}$ & $00 \mathrm{R}$ & $00 \mathrm{R}$ & $21 \mathrm{I}$ & $20 \mathrm{~S}$ & $00 \mathrm{R}$ & $00 \mathrm{R}$ \\
\hline 9242 & C. glabrata & $22 \mathrm{~S}$ & $00 \mathrm{R}$ & $00 \mathrm{R}$ & $00 \mathrm{R}$ & $00 \mathrm{R}$ & $10 \mathrm{R}$ & $00 \mathrm{R}$ & $00 \mathrm{R}$ \\
\hline 9244 & C. glabrata & $15 \mathrm{~S}$ & $00 \mathrm{R}$ & $00 \mathrm{R}$ & $00 \mathrm{R}$ & $00 \mathrm{R}$ & $27 \mathrm{~S}$ & $00 \mathrm{R}$ & $00 \mathrm{R}$ \\
\hline 9245 & C. glabrata & $16 \mathrm{~S}$ & $00 \mathrm{R}$ & $00 \mathrm{R}$ & $00 \mathrm{R}$ & $00 \mathrm{R}$ & $27 \mathrm{~S}$ & $00 \mathrm{R}$ & $00 \mathrm{R}$ \\
\hline 9246 & C. albicans & $20 \mathrm{~S}$ & $21 \mathrm{~S}$ & $30 \mathrm{~S}$ & $13 \mathrm{R}$ & $00 \mathrm{R}$ & $25 \mathrm{~S}$ & $00 \mathrm{R}$ & $27 \mathrm{~S}$ \\
\hline 9247 & C. krusei & $9 \mathrm{R}$ & $20 \mathrm{~S}$ & $15 \mathrm{I}$ & $00 \mathrm{R}$ & $11 \mathrm{R}$ & $21 \mathrm{~S}$ & $10 \mathrm{R}$ & $10 \mathrm{R}$ \\
\hline 9248 & C. albicans & $17 \mathrm{~S}$ & $00 \mathrm{R}$ & $00 \mathrm{R}$ & $14 \mathrm{I}$ & $25 \mathrm{I}$ & $22 \mathrm{~S}$ & $21 \mathrm{I}$ & $35 \mathrm{~S}$ \\
\hline
\end{tabular}




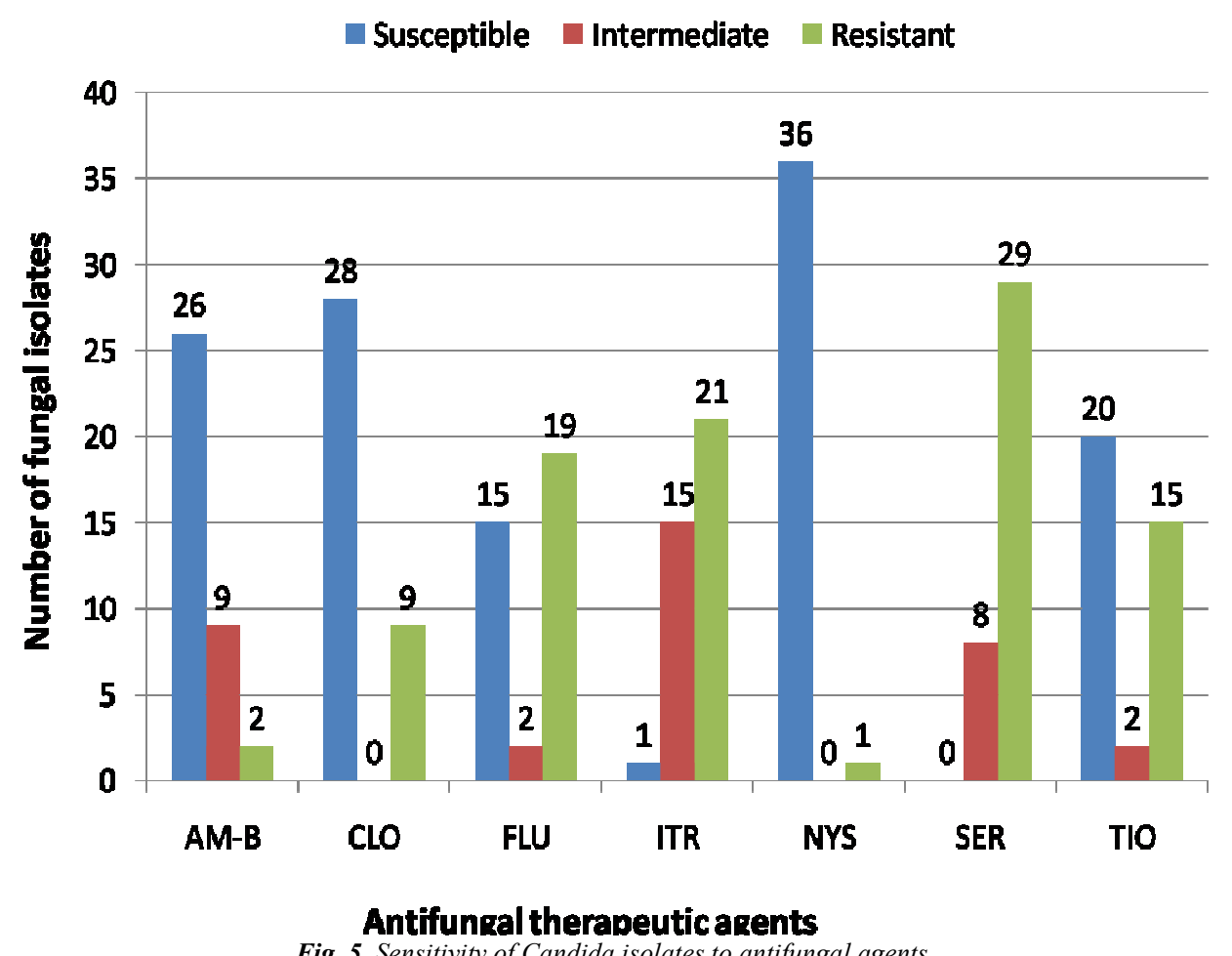

\section{Acknowledgement}

The authors are greatly indebted to all colleagues in the Universities of Cairo, Assiut and Sohag for making urine samples available from hospitalized patients. Sincere thanks are due to staff members and researchers at the Assiut University Mycological Centre (AUMC)for all research facilities they have provided.

\section{References}

[1] Álvarez-Lerma, F.; Nolla-Sallas, J.; Palomar, M.; Jordá, R.; Carrasco, N. and Bobillo, F.( 2003): Candiduria in critically ill patients Admitted to intensive care medical units. Inten Care Med 29:1069-1076.

[2] Ang B. S. P., A. Telenti, B. King, J. M. Steckelberg and W. R. Wilson (1993): "Candidemia from a urinary tract source: microbiological aspects and clinical significance", Clin. Infect. Dis., 17, 662-666.

[3] Ayeni, O. Riederer, KM. Wilson, FM. and Khatib, R.(1999): Clinicians' reaction to positive urine culture for Candida organisms. Mycoses,42:285-9.

[4] Badawi H., A. I. Kamel, N. Fam, M. El-Said and S. Elian (2004): "Candida urinary infections: emerging species, antifungal Susceptibility trends and antibody response", Egypt J.Med. Microbiol., 13 (1), 1-14.

[5] Bakir, M., N. C. Cerikciog `lu, A. Tirtir, S. Berrak, E. O־ zek, and C. Canpolat.2003. Pichia anomala fungaemia in immunocompromised children. Mycoses47:231-235.
[6] Banerjee. SN.; Emori, TG.; Culver, DH.; Gayness, PP. ;Jarvis, WR.; Hovan, T. Edwards, JR.; Tolson, J.; Herderson, T. and Martone, WJ. (1991): Secular trends in nosocomial primary bloodstream infections in he United States, 1980 - 1989.

[7] National nosocomial Infections surveillance system. Am J Med 91-3B,86S-89S.

[8] Behiry, I. K.; El Hedeki, S. KH. and Mahfouz,M.(2010):Candida infection associated with urinary catheter in critically ILL patients. Identification, antifungal susceptibility and risk factors. Research Journal of Medicine and Medical Science,5(1):79-86.

[9] Berrouane, Y. F., Herwaldt, L. A. \& Pfaller, M. A. (1999). Trends inantifungal use and epidemiology of nosocomial yeast infections ina university hospital. J Clin Microbiol 37, 531-537.

[10] Bhavan, PS.; Rajkumar, R.; Radhakrishnan, S.; Seenivasan, C. and Kannan, S. (2010): Culture and Identification of Candida albicans from Vaginal Ulcer and Separation of Enolase on SDS-PAGE. Interna J Biol; 2:84-93.

[11] Bukhary, Z. A.(2008): Candiduria: A review of clinical significance andmanagement. Saudi J Kidney Dis Transpl. 19:350-60.

[12] Campbell, C.K.; Holmes, A.D.; Davey, K.G.; Szekely, A.; Warnock,D.W. (1998): Comparison of a new chromogenic agar with the germ tube method for presumptive identification of Candida albicans. Eur J Clin Microbiol Infec Dis 17: 367-8.

[13] Coleman, D. C.; Bennett, D. E.; Gallagher,P. J.; Flint, S. R.; Nolan, A.;Mulcahy, F. M.; Sullivan, D. J.;Henman, M. C.; Russell, R. J. And Shanley, D. B. (1995): Oral candidiasis and HIV infection: anti-fungal drug resistance and changes 
in Candida population dynamics. In: Greenspan JS,Greenspan D, Greenspan JS, Greenspan D (eds) Oral manifestations of HIVinfection. Quintessence publishing Company, Chicago, IL.

[14] Coleman, D. C.; Bennett, D. E.; Sullivan,D. J.; Gallagher, P. J.;Henman, M. C.; Shanley, D. B. and Russell,R. J. (1993): Oral Candida in HIV infection and AIDS: new perspectives/new approaches. Crit.Rev. Microbiol., 19:61-82.

[15] Conceição, G.C.; Coelho, P.P.; Sousa Junior, M.A.; Pereira, M.L.;Miguel, D.S.C.G.; Toralles, M.B.P. (2005): Avaliação do teste tubo germinativo em secreção vaginal a fresco para triagem de Candida albicans: um teste rápido. Newslab 73: 106-12.

[16] Ellis D, Davis S, Alexiou H, Handke R, and Bartley R. (2007): Descriptions of medical fungi. 2nd edition. Nexus Print Solutions, Australia. p. 20-40.

[17] Ellis, D. (2011 a): Antifungal susceptibility testing. (NeoSensitab and E-test methods. Notes on disc diffusion and Etest methods). Mycology Online. The University of Adelaide CRICOS Provider No. 00123M.

[18] Ellis, D. (2011b): Antifungal susceptibility profile (Australian antifungal susceptibility data for Candida isolates from recurrent volvovaginal candidiasis (2007-2009) using the CLSI M44-A2 disc susceptibility standard for yeasts). Mycology Online. The University of Adelaide. CRICO Provider N. 00123M.

[19] Febré, N.; Silva, V.; Medeiros, EAS.; Wey, SB.; Colombo, AL.and Fischman, O. (1999): Microbiological characteristics of yeasts isolated from urinary tracts of intensive care unit patients undergoing urinary catherization. J Clin Microbiol 37: 1584-1586.

[20] Fisher, F.; Cook, N. (1998): Reagents, stains, media and methods. In:Fisher, F. \& Cook, N. (eds) Fundamentals of diagnostic mycology.Saunders, 320-340.

[21] Gatica, J.L.M.; Goic, I.B.; Martinez, M.A.T. et al. (2002): Utilidad del agar cromocandida para el diagnostico diferencial de Candida spp aisladas de muestras vaginales. Rev Chil Obstet Ginecol 67: 300-304.

[22] Girgis, S. A., El-Mehalawy, A. A. and Rady, L. M. (2009 Comparison between culture and non-culture based methods for detection of Nosocomial fungal infections of Candida spp.in intensive care unit patients. Egypt. Acad. J. biolog. Sci. 1: 37-47.

[23] Godoy, P.; Almeida, L.P.; Colombo, A.L. (2001): Identificación de Candida albicans utilizando el medio cromogénico Albicans ID. Rev Iberoam Micol 18: 197-199.

[24] Guler,S.,Ural,O.,Findik,D.andArslan,U.(2006):Risk factors of nosocomial candiduria. Saudi Med J.; Vol 27 (11): 17061710 .

[25] Jain N., Kohli R., Cook E., Gialanella P., Chang T.,(2007): Biofilm Formation by and Antifungal Susceptibility of Candida Isolates from Urine Applied and Environmental Microbiology, 73: 1697-1703.

[26] Javris, WR.; Edwards, JR. and Culver, DH.et al. (1999): Nosocomialinfection rates in adult and pediatric intensive care units in the United States.National Nosocomial Infections Surveillance System.Amer J Med, 91:185S-9S.
[27] Kangogo, M.C.; Wanyoike,M.W.; Revathi,G. and Bii, C.C. (2011):Phenotypic characterization of Candida albicans from clinical sources in Nairobi, Kenya. Afr.J.Health Sci.19:19-23.

[28] Kauffman C. A., J. A. Vazquez, J. D. Sobel,H. A. Gallis, D. S. McKinsey, A. W.Karchmer, A. M. Sugar, P. K. Sharkey, G. J. Wise, R. Mangi, A. Mosher, J. Y. Lee, and W. E. Dismukes (2000): "Prospective multicenter surveillance study of funguria in hospitalized patients", ibid., 30, 14-18.

[29] Kauffman, CA.(2005); Candiduria. Clin Infect Dis.41: 371 376.

[30] Kauffman, CA.; Vazquez, JA.; Sobel, JD.; Gallis, HA.; McKinsey, DS. and Karchmer, AW. et al . (2000): Prospective multicenter surveillance study of funguria in hospitalized patients. Clin Infect Dis. 30:14-8.

[31] Khlif,M.; Sellami,H.; Sellami, A. ; Makni, F.; Cheikhrouhhou, F.; Chelly, H.; Bouaziz, M.and Ayadi,A.(2007): Detection and identification of Candida sp. By PCR in candidemia diagnosis.J.deMycologie Medicale, 17:256-260.

[32] Klotz, S., and R. Smith. 1990. Candida albicans adherence to subendothelial extracellular matrix components is inhibited by arginine-glycine-aspartic acid peptides. Clin. Res. 38:13A.

[33] Kobayashi, CC.; de Fernandes, OF.; Miranda, KC.; de Sousa, ED.and Silva, Mdo. R.(2004): Candiduria in hospital patients: A study prospective. Mycopathologia;158: 49-52.

[34] Koehler, A. P., Chu, K. C., Houang, E. T. \& Cheng, A. F. (1999). Simple, reliable and cost effective yeast identification scheme for the clinical laboratory. J Clin Microbiol 37, $422-426$.

[35] Kronvall,G. And Karlsson, I.(2001): Fluconazole and Voriconazole Multidisk Testing of Candida Species for Disk Test Calibration and MIC Estimation.J.Clin.Microbiol. 39: 14221428.

[36] Lacaz, C.S.; Porto, E.; Martins, J.E.C. et al. (2002): Leveduras deinteresse médico. In: Lacaz, C.S., Porto, E., Martins, J.E.C, Vaccari-Heins, E.M., De Melo, N.T. (eds) Tratado de MicologiaMédica. SãoPaulo: Sarvier, 123-73.

[37] Lundstrom T and Sobel J.( 2001): Nosocomial candiduria: A review. Clin Infect Dis. 32:1602-1607.

[38] Milan, E.P.; Zaror, L. (2004): Leveduras: identificação laboratorial. In:Sidrim, J.J.C. \& Rocha, M.F.G. (eds) Micologia Médica à luz de Autores contemporâneos. Rio de Janeiro: Guanabara Koogan, 89-101.

[39] Nawrat, U; Grzybek-Hryncewicz, K and Karpiewska, A. (2000): Susceptibilty of Candida species to antimycotics determined by microdilution method. Mikol. Lek. 7: 19-26.

[40] Orovcova E., J. Lacka, L. Drgona, M.Studena, L. Sevcikova and S. Spanik (1996):"Funguria in cancer patients: analysis of risk factors, clinical presentation and outcome in 50 patients", Infection, 24, 319- 323.

[41] Otag, F. et al. (2005): An outbreak of Pichia ohmeri infection in the paediatric intensive care unit: case reports and review of the Literature.Mycoses 48, 265-269.

[42] PakshirK., M. Moghadami, M. Emami and P. Kord Bacheh(2004): "Prevalence and identification of etiological 
agents of funguria in Foley catheterized patients", J.Med. Res. Shiraz. Univ. Med. Sci. 3, 33-41.

[43] Passos, XS.; Sales, WS.; Maciel, PJ.; Costa, CR.; Miranda, KC. andLemos, Jde. A.(2005): Candida colonization in intensivecare unit patients' urine. Mem Inst Oswaldo Cruz;100: 925-928.

[44] Pfaller, M.A.;S.A. Messer, R.J. Hollis, R.N. Jones, G.V.Doern, M.E.Brandt and R. A. Hajjeh (1991):Trends in species distribution and susceptibility to fluconazole among blood stream isolates of Candida species in the United States.Diagn. Microbiol. Infect. Dis. 33:217-222.

[45] Pfaller, MA.; Houston, A.and Coffmann S. (1996): Application of CHROMagarCandida for rapid screening of clinical specimens for Candida albicans, Candida tropicalis, Candida krusei, and Candida (Torulopsis) glabrata. J Clin Microbiol; 34:58-61.

[46] Platt, R.; Polk, BF.; Murdock, B. and Rosner, B.(1986):Risk factors for nosocomial urinary tract infection. Amer J Epidemiol, 124:977-985.

[47] Rashwan,N.M.Mohamed,AK.A. Saif El-Deen,S. Ahmed,E.H. and Imail,S.A.(2010): Pattern of Candida urinary tract infections among cancer patients in south Egypt Cancer Institute. Bull. Pharm. Sci., Assiut University, 33:121-130.

[48] Schaberg,D.R., D.H.Culver and R.P.Gaynes (1991):Major trends in the microbial etiology of nosncomial etiology of nosocomial infections .AM.J.Med.91:72S-75S.

[49] Schonebeck,J. and Ansehn, S. (1972): The occurrence of yeast-like fungi in the urine under normal conditions and in various types of urinary pathology. Scand J Urol Nephrol. $6: 123-8$.

[50] Shay, AC. and Miller, LG.(2004):An estimate of the incidence ofCandidutia among hospitalized patients in the United States. Infect Control Hosp Epi-demiol , 25:894-5.
[51] Sobel, JD. and Vasquez, JA. (1999): Fungal infections of the urinarytract. World J Urol 17, 410-414.

[52] Sobel JD, Kauffman CA, Mckinsey D, et al.(2000) Candiduria: A randomized, double-blind study of treatment with fluconazole and placebo. Clin Infect Dis. 30(1):19-24.

[53] Sobel, J. D. (2007): Vulvovaginal candidosis. Lancet, 369:1961-1971.

[54] Storfer S P, Medoff G, Fraser VJ, Powderly WG and Dunagan WC (1994): Candiduria: retrospective review in hospitalized patients Infect Dis Clin Pract. 3:23-29.

[55] Sulivan, DJ.; Westerneng, TJ.; Haynes, KA.; Bennett, DE. and Coleman, DC. (1995): phenotypic and molecular characterization of a novel species associated with oral candidosis in HIV-infected individuals. Microbiology 141: $507-$ 1521.

[56] Vidigal, P G, Santos, S A, Fernandez M A, Bonfim P S 1, Martinez H V and Svidzinski T E (2011): Candiduria by Candida tropicalis evolves to fatal candidemia. Medical Case Studies 2: 22-25.

[57] Vijaya D., Harsha T.R.and Nagaratnamma T.(2011):Candida Speciation Using Chrom Agar.Journal of Clinical and Diagnostic Research. Vol-5(4): 755-757.

[58] VincentJ. L., E. Anaissie, H. Bruining, W.Demajo, M. EIEbiary and J. Haber (1998): "Epidemiology, diagnosis and treatment of systemic Candida infection in surgical patients under Intensive care", Intensive Care Med. 24: 206-216.

[59] Wainer, S.;Cooper, PA.;Gouws, H. and Akierman, A. (1997): Prospective study of fluconazole therapy in systemic neonatal fungal infection. Pediatr Infect Dis J. 16:763-767.

[60] Weinberger M., S. Sweet, L. Leibovici, S.D. Pitlik and Z. Samra (2003): "Correlation between candiduria and departmental antibiotic use", J. Hosp. Infect., 53, 183-186. 